\title{
Management of puddled soil through organic amendments for post-rice mungbean
}

\author{
Md Arafat Hossain'1, Md Masud Rana2 ${ }^{2}$, S M Hisam Al Rabbi' ${ }^{1}$, Toshiaki Mitsui ${ }^{3}$ \\ ${ }^{1}$ Biotechnology Division, Bangladesh Rice Research Institute, Gazipur-1701, Bangladesh \\ ${ }^{2}$ Agronomy Division, Bangladesh Rice Research Institute, Gazipur-1701, Bangladesh \\ ${ }^{3}$ Department of Life and Food Sciences, Graduate School of Science and Technology, Niigata University, Niigata 950-2181, Japan
}

Received:

May 02, 2020

Accepted:

June 16, 2020

Online First:

July 30, 2020

Published:

January 30, 2021
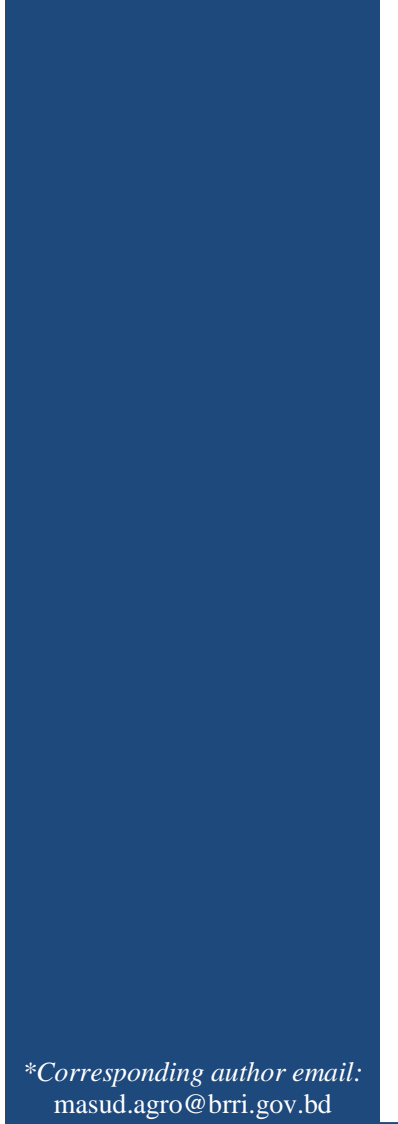

Keywords: Bulk density, Crop residue, Mungbean, Organic-C, Puddling intensity and soil

\section{How to cite this:}

Hossain MA, Rana MM, Al Rabbi SMH and Mitsui T, 2021. Management of puddled soil through organic amendments for post-rice mungbean. Asian J. Agric. Biol. 2021(1). DOI: https://doi.org/10.35495/ajab.2020.04.255

This is an Open Access article distributed under the terms of the Creative Commons Attribution 3.0 License. (https://creativecommons.org/licenses/by/3.0), which permits unrestricted use, distribution, and reproduction in any medium, provided the original work is properly cited. 


\section{Introduction}

Mungbean (Vigna radiata L.) is economically important edible pulse widely grown and consumed in South, East and Southeast Asian countries. It is highly rich in protein, minerals and vitamins, and contributing to food and nutritional security in developing countries (Hou et al., 2019). In Bangladesh, mungbean is usually grown as a cash crop in the Kharif1 season (March- July), occupying 37651 ha of land with a production of $34000 \mathrm{~m}$ tons (BBS, 2019). It is also cultivated to enrich the soil health and to utilize the residual soil moisture following rice cultivation. Now the crop is extensively grown in the southern and northwest regions of Bangladesh. In southern region, the crop is planted on land previously occupied by irrigated rice. In general, heavy clay soils are puddled intensively for rice cultivation that may be unneeded. The physical structure of soil deteriorates more as a result of intense puddling, and increasing puddling intensity increased the bulk density of soil (Rezaei et al., 2012). After completion of each puddling, the particles settle down and subsequently increase particle density.

Poor physical properties of soil after rice cultivation are the key limiting factors for successful upland crops establishment in many Asian countries including Bangladesh (Harris et al., 1999; Rahmianna et al., 2000; Musa et al., 2001; Singh et al., 2020). Bangladeshi farmers often cultivate their crops late and cannot prepare their land adequately because of quick run out of soil moisture in wet puddled soil previously occupied by rice. Soil puddling is considered beneficial for rice, but the puddling intensity level is not well established. Soil conditions following puddling and drying was found unsuitable for succeeding upland leguminous crops giving less yields because of poor root development (Kirby and RingroseVoase, 2000; Bell et al., 2019; Salahin et al., 2019).

Research directing to changing soil physical conditions resulting from differential puddling and thereby application of various management techniques for suitable yield of Vigna spp under such situation is inadequate rather fragmentary. Several studies support that the fundamental soil constraints limiting the plant growth and development include high soil permeability, soil crusting, sub-surface mechanical impedance and soil hardening (Kirchhof et al., 2000; Srinivasarao et al., 2019; Yuvaraj, 2020).

The mitigation of important soil physical problems that hinder crop growth and development is vital for enhancing the agricultural production and maintaining the soil health (Obalum et al., 2012; Fang et al., 2018; Lim et al., 2020). Incorporation of organic amendments (Sesbania spp, farmyard manure, crop residue etc) reduced the $\mathrm{N}$ requirement and improving the soil sub-surface mechanical impedance under rice-wheat cropping system (Phogat and Dahiya, 2012; Williams et al., 2020). When mungbean is grown in rotation with rice, the use of organic amendments is environmentally safer, and the amendments efficiently improve the soil physicochemical properties (Becker et al., 2008). The cultivation of post-rice mungbean with the incorporation of organic fertilizer can overcome the problem of declining soil fertility and may improve the productivity of mungbean. For sustaining growth and increasing crop production, soil structural improvement as well as ensuring availability of nutrients is a must under post-rice condition. For this, identification of soil physical constraints including changes in chemical properties that limit crop growth and fine-tuning suitable practices for their management are vital for changing soil productivity and assured sustainability of crop production. The present study was undertaken to assess the effects of organic residue incorporation after harvesting wetland rice on physico-chemical properties of puddled soil and the growth and yield of mungbean. This is the first study for optimizing mungbean seed yield and to improve soil physico-chemical properties through incorporation of organic amendment in the wetland rice soil of Bangladesh.

\section{Material and Methods}

\section{Experimental plan and management}

The experiment was carried out at the Field Laboratory of Bangabandhu Sheikh Mujibur Rahman Agricultural University, Gazipur, Bangladesh. The location of site is at $24^{\circ} 05^{\prime} \mathrm{N}$ latitude and $90^{\circ} 25^{\prime} \mathrm{E}$ longitude. The soil of the experimental field was man made under Madhupur Tract (AEZ 28). The average temperature ranged between $21^{\circ} \mathrm{C}$ to $35^{\circ} \mathrm{C}$ during the experimentation. The soil texture was loamy clay and slightly acidic in reaction with very low $\mathrm{N}$ and $\mathrm{P}$ content. Rice was grown previously in the field under three puddling situations i.e. no puddling, puddling by four passes, and puddling by eight passes to create ideal condition for the experiment. One pass means a single run of power tiller across the experimental unit. No puddling situation was the dry tillage condition using 


\section{Md Arafat Hossain et al.}

power tiller. Field condition was set for post rice mungbean production where three management practices i.e. crop residue, cow dung management, and control plot were placed in three puddling situations. Both puddling and management practices were considered as the treatment variables. The variety used in this experiment was BU mug 4 . The experiment was carried out in a randomized complete block design (RCBD) and all possible treatment combinations were replicated four times. The size of the experimental unit plot was $2.4 \times 2.4 \mathrm{~m}$. Mungbean was seeded following recommended spacing $(30 \times 10 \mathrm{~cm})$. Fertilizers (urea @ $50 \mathrm{~kg} \mathrm{ha}^{-1}$, TSP @ $85 \mathrm{~kg} \mathrm{ha}^{-1}$, MOP @ $35 \mathrm{~kg} \mathrm{ha}^{-1}$ ) were applied as per recommendation of fertilizer recommendation guide. Two management practices i.e. incorporation of crop residue and addition of cow dung were tested and compared with control condition. Rice straw as crop residue @ 1.3 ton ha ${ }^{-1}$ and cow dung @ 6.04 ton ha ${ }^{-1}$ were incorporated at the time of final land preparation. Seeds were sown on puddled soil following furrow method. Seeds were primed with water for four hours before seeding. Field was kept weed free by hand weeding at 15 and 30 days after emergence (DAE) and adequate plant protection measures were taken to keep the plants free from insects and diseases.

\section{Initial soil sampling and measurement of bulk density}

Soil sampling was done prior to commencing the experiment with the help of a core sampler to measure soil bulk density (Blake, 1965). Twelve soil samples were collected randomly from the main plots imposing pudding treatments. The samples were brought to the laboratory and fresh weight were taken immediately and at the same time sub-samples were taken into can and oven dried at $105^{\circ} \mathrm{C}$ for 72 hours and then weighed it. Bulk density of the collected soil was determined using the following formula:

Bulk density $\left(\mathrm{g} \mathrm{cc}^{-1}\right)=\frac{\text { Weight of fresh soil }}{\text { Inner volume of core sampler }\left(\pi r^{2} h\right)} \times \mathrm{K}$

Where, $\mathrm{K}=$ weight of dry soil/ weight of moist soil

$\pi=3.1416$ (constant)

$\mathrm{r}=$ core sampler radius $(\mathrm{cm})$

$\mathrm{h}=$ core sampler height $(\mathrm{cm})$

Soil moisture measurements

Soil moisture was measured six times at 5, 10, 15,
20 , and 25 days after saturation and finally after harvest by core sampler. The operation was done by collecting fresh samples from surface soil and dried at $105{ }^{\circ} \mathrm{C}$ for 72 hours or up to constant weight and then weighed it. The difference between fresh soil and oven dried soil showed the moisture content. Soil moisture was measured in 12 main plots and in each case the mean of three readings at each level was calculated. Determination of soil moisture content was done according to Kramarenko et al. (2016) as:

Soil moisture $(\%)=\frac{\text { Soil fresh weight }- \text { Oven dry soil weight }}{\text { Soil fresh weight }} \times 100$

\section{Analysis of soil chemical properties Soil pH}

Soil solution was made with $10 \mathrm{~g}$ soil adding with $25 \mathrm{~mL}$ distilled water using electro-magnetic stirrer. Finally, a $\mathrm{pH}$ meter was used to take the sample reading.

\section{Organic carbon}

Wet oxidation method was followed as outlined by Adams (1934) where $1 \mathrm{~g}$ soil was homogenized with $10 \mathrm{~mL}$ potassium dichromate $(1 \mathrm{~N})$. Then $10 \mathrm{ml}$ concentrated $\mathrm{H}_{2} \mathrm{SO}_{4}$ was added. Then solution was heated in sand bath for 10 minutes. After cooling down, the solution was titrated with $0.2 \mathrm{~N}$ ferrous ammonium sulfate using phenyl anthranalic acid indicator.

\section{Total nitrogen}

Total-N was quantified using micro-Kjeldahl digestion method (Chu et al., 2004), where $1 \mathrm{~g}$ soil was taken into a Kjeldahl flask and $3 \mathrm{~g}$ catalyst (potassium sulphate + copper sulphate) was added. Then $10 \mathrm{~mL}$ concentrated $\mathrm{H}_{2} \mathrm{SO}_{4}$ was added. The flask was set into digestion chamber for 2 hours. After cooling down the solution was poured into a $100 \mathrm{~mL}$ volumetric flask and filled up with distilled water up to marked level. Then $10 \mathrm{~mL}$ solution was distilled by $40 \% \mathrm{NaOH}$ and the distilled solution was taken into $100 \mathrm{~mL}$ conical flask where $10 \mathrm{~mL}$ boric acid was added previously. Finally, $50 \mathrm{~mL}$ distilled solution was titrated using $0.02 \mathrm{~N} \mathrm{H}_{2} \mathrm{SO}_{4}$.

\section{Available phosphorus}

Available-P was extracted by $0.5 \mathrm{M} \mathrm{NaHCO}_{3}(\mathrm{pH} 8.5)$ and determined colorimetrically following molybdate blue method (Olsen and Dean, 1954) where $5 \mathrm{~g}$ soil was mixed in $50 \mathrm{~mL} \mathrm{NaHCO} 3(0.5 \mathrm{M})$. Then the solution was shaken for 30 minutes and filtered by 
Whatman 42 filter paper. A $10 \mathrm{~mL}$ filtrate was taken in a $50 \mathrm{~mL}$ volumetric flask. Then 2 drops phosphorus nitro-phenol $(0.25 \%)$ was added. After appearing yellow color, $5 \mathrm{~N} \mathrm{H}_{2} \mathrm{SO}_{4}$ was added drop wise until the color disappears. Then $8 \mathrm{~mL}$ mixed reagent was added, and $50 \mathrm{~mL}$ volume was filled up by adding distilled water. Color of the solution turned into blue and waited for 30 minutes. Finally, absorption of the solution was measured by spectrophotometer.

\section{Available potassium}

Available-K was extracted by ammonium acetate solution and determined by atomic absorption spectrophotometer (Murphy, 1987) where $2.5 \mathrm{~g}$ soil was mixed in $25 \mathrm{~mL}$ Ammonium Acetate solution. Solution was shaken for 30 minutes and kept overnight. After that the solution was filtered by Whatman 42 filter paper. Finally, absorption of the filtrate was measured by atomic absorption spectrophotometer.

\section{Growth measurement}

To record morphological and physiological characters six plants from each treatment were randomly selected. Data were recorded from these selected plants at 10 days intervals starting from 20 DAE and continued up to 60 DAE. Data on plant height and the plants were partitioned into roots, stems, petiole, leaf and reproductive parts were recorded at each sampling. At the same time, leaf area of each plant was also measured. The plant height was taken from the base to the tip of the plant and the means of plant height were calculated. For dry matter estimation, the sampled plants were dried to a constant weight at $70{ }^{\circ} \mathrm{C}$ for 72 hours in a drier and then weighed. The area of four leaves of the sample plants was quantified using a leaf area meter (AAM-7, Hayshi Denkoh Co. Ltd., Tokyo, Japan). Then the total green leaves area of six sampled plants were measured and averaged.

\section{Crop characters}

At final harvest the crop characters such as, pod number plant ${ }^{-1}$, number of seeds pod $^{-1}$, pod length, thousand-seed weight, total biomass and seed yield were measured. Pods were harvested at wellmatured condition and seed yield was calculated by summing the three harvests. The weight of the grains harvested from each plot was converted into ton per hectare. At maturity, 10 plant samples were uprooted to measure yield and yield contributing characters. The seeds were counted by automatic seed counter to take 1000 -seed weight. Determination of harvest index was done by dividing the economic yield (grain) by the biological yield (grain + biomass) achieved from the same area.

\section{Statistical analysis}

Collected different parameters data were analyzed following analysis of variance (ANOVA) according to the technique reported by Gomez and Gomez (1994) using MSTAT program and the mean differences were compared by LSD method $(\mathrm{p}<0.05)$.

\section{Results and Discussion}

\section{Bulk density and moisture content of soil affected by puddling intensity}

From the result (Table 1) it is revealed that bulk density increased to a great extent as the intensity of puddling increased. Obalum et al., 2012 reported that puddling a well aggregated soil creates a massive structure with high bulk density that increases with drying because of soil shrinkage. In general, the surface soil structure altered by puddling becomes unsuitable for the successful cultivation of legume. The plant growth and yield of legume grown after rice is negatively affected by the poor soil physical conditions that imposed significant resistance to root penetration (Bajpai and Tripathi, 2000).

Table-1. Soil bulk density ( cc $^{-1}$ ) as influenced by different puddling intensity

\begin{tabular}{|c|c|c|c|c|c|}
\hline \multirow{2}{*}{ Puddling intensity } & \multicolumn{5}{|c|}{ Days after saturation } \\
\cline { 2 - 6 } & $\mathbf{5}$ & $\mathbf{1 0}$ & $\mathbf{1 5}$ & $\mathbf{2 0}$ & $\mathbf{2 5}$ \\
\hline No puddling & $1.31 \mathrm{c}$ & $1.34 \mathrm{c}$ & $1.36 \mathrm{c}$ & $1.37 \mathrm{c}$ & $1.40 \mathrm{c}$ \\
\hline Puddling by 4 passes & $1.40 \mathrm{~b}$ & $1.43 \mathrm{~b}$ & $1.46 \mathrm{~b}$ & $1.49 \mathrm{~b}$ & $1.52 \mathrm{~b}$ \\
\hline Puddling by 8 passes & $1.44 \mathrm{a}$ & $1.48 \mathrm{a}$ & $1.51 \mathrm{a}$ & $1.54 \mathrm{a}$ & $1.58 \mathrm{a}$ \\
\hline
\end{tabular}

Different letters in the same column indicate significant difference (Duncan's test, $P<0.05$ ).

The lowest bulk density was observed in no puddling situation) which is significantly higher when puddling intensity increased. The highest bulk density (1.58 g $\mathrm{cc}^{-1}$ ) was recorded when puddling was done by 8 passes 25 days after saturation. This indicates that puddling activities generally increased soil bulk density. But after harvest a significant reduction in bulk density has been observed. The reduction was highest in puddling by 4 passes situation. Other puddling situations did not have significant effects. Soil puddling degrades structure by reducing 


\section{Md Arafat Hossain et al.}

macropores and increasing the total porosity (Kirchhof et al., 2000).

Table-2. Soil moisture content (\%) as affected by different puddling conditions

\begin{tabular}{|c|c|c|c|c|c|}
\hline \multirow{2}{*}{ Puddling intensity } & \multicolumn{5}{|c|}{ Days after saturation } \\
\cline { 2 - 6 } & 5 & 10 & 15 & 20 & 25 \\
\hline No puddling & $29.91 \mathrm{~b}$ & $25.41 \mathrm{~b}$ & $20.58 \mathrm{~b}$ & 15.43 & 7.59 \\
\hline Puddling by 4 passes & $33.01 \mathrm{a}$ & $27.29 \mathrm{a}$ & $22.48 \mathrm{ab}$ & 16.70 & 8.44 \\
\hline Puddling by 8 passes & $35.16 \mathrm{a}$ & $29.06 \mathrm{a}$ & $23.59 \mathrm{a}$ & 17.56 & 8.36 \\
\hline Different letters in the same column indicate
\end{tabular}

significant difference (Duncan's test, $P<0.05$ ).

Soil moisture content significantly increased with increasing puddling intensity in surface soil at five days after saturation (Table 2). Moisture content was always higher in puddling by 8 passes situation compared to other no puddling and puddling by 8 passes situations. After saturation soil moisture content depletes with time which varies for different puddling situations. Moisture depletion was comparatively slow in case of puddling by 8 passes situation at early stage after saturation. At 20 and 25 days after saturation moisture content was non-significant for all puddling situations.

However, after harvest, soil moisture content was higher again in puddling by 8 passes situation compared to no puddling and puddling by 4 passes situation. Zhou et al. (2014) agreed that alternate wetting and drying of lowland puddled soil decrease the organic-C, activities of soil microbes, thereby deteriorate the soil physical properties.

\section{Soil chemical properties affected by soil puddling} and different management practices

Soil $\mathrm{pH}$ has degraded after ploughing and application of different organic amendments (Table 3). In case of puddling, the highest degradation occurs in puddling by 8 passes condition $(4.17 \%)$. But $\mathrm{pH}$ values among different puddling intensities were insignificant indicating puddling intensity had no significant effect on soil $\mathrm{pH}$. In case of different management practices, cow dung management showed the highest degradation (5.02\%) from initial $\mathrm{pH}$. In crop residue and control management degradation was almost similar. Significant difference has been found among the $\mathrm{pH}$ values for different management practices after harvest. Soil $\mathrm{pH}$ was lowest in cow dung management. Crop residue management showed moderate result and control management gave the highest values which specify that application of cow dung decreases soil $\mathrm{pH}$. Puddling had no significant effect on accumulation of total-N, available-P, exchangeable-K and organic-C (Table 3).

The amount of total-N, available-P, exchangeable-K and organic-C (\%) increased in all puddling situations from the initial value. But there were no significant differences among the three puddling intensities for accumulation of available $\mathrm{N}, \mathrm{P}, \mathrm{K}$, and organic-C. Total-N, available-P, exchangeable-K, and percent of organic-C have been increased after application of different organic amendments.

Table-3. Soil chemical properties influenced by soil puddling and different management practices

\begin{tabular}{|c|c|c|c|c|c|}
\hline \multirow[b]{2}{*}{ Treatments } & \multicolumn{5}{|c|}{ Chemical properties of soil } \\
\hline & Soil pH & Total N (\%) & $\begin{array}{c}\text { Available } P \\
(\mu g m / 100 g \text { soil })\end{array}$ & $\begin{array}{c}\text { Exchangeable } \mathrm{K} \\
\text { (meq/100g soil) }\end{array}$ & $\begin{array}{c}\text { Organic matter } \\
(\%)\end{array}$ \\
\hline Initial value & 6.48 & .005 & 13.21 & 0.11 & 0.90 \\
\hline \multicolumn{6}{|c|}{ Puddling intensity } \\
\hline No puddling & $\begin{array}{c}6.34 \\
(-2.16) *\end{array}$ & $\begin{array}{c}0.011 \\
(+120)^{*}\end{array}$ & $20.56(+55.64)^{*}$ & $\begin{array}{c}0.17 \\
(+54.55)^{*} \\
\end{array}$ & $\begin{array}{c}1.50 \mathrm{a} \\
(+66.67)^{*}\end{array}$ \\
\hline Puddling by 4 passes & $\begin{array}{c}6.32 \\
(-2.47) *\end{array}$ & $\begin{array}{c}0.011 \\
(+120)^{*}\end{array}$ & $\begin{array}{c}21.90 \\
(+65.78)^{*}\end{array}$ & $\begin{array}{c}0.16 \\
(+45.45)^{*}\end{array}$ & $\begin{array}{c}1.40 \mathrm{a} \\
(+55.56)^{*}\end{array}$ \\
\hline Puddling by 8 passes & $\begin{array}{c}6.21 \\
(-4.17)^{*}\end{array}$ & $\begin{array}{c}0.010 \\
(+100)^{*}\end{array}$ & $\begin{array}{c}21.76 \\
(+64.72)^{*} \\
\end{array}$ & $\begin{array}{c}0.16 \\
(+45.45)^{*}\end{array}$ & $\begin{array}{c}1.41 \mathrm{~b} \\
(+56.67)^{*}\end{array}$ \\
\hline \multicolumn{6}{|c|}{ Management practices } \\
\hline Control & $\begin{array}{c}6.39 a \\
(-1.40)^{*}\end{array}$ & $\begin{array}{l}0.008 \mathrm{c} \\
(+60)^{*}\end{array}$ & $\begin{array}{c}18.32 \mathrm{c} \\
(+38.68)^{*} \\
\end{array}$ & $\begin{array}{c}0.15 \mathrm{~b} \\
(+36.36)^{*}\end{array}$ & $\begin{array}{c}1.21 \mathrm{c} \\
(+34.44)^{*} \\
\end{array}$ \\
\hline Crop residue & $\begin{array}{c}6.31 \mathrm{ab} \\
(-2.62)^{*}\end{array}$ & $\begin{array}{l}0.010 \mathrm{~b} \\
(+100)^{*}\end{array}$ & $\begin{array}{c}21.08 \mathrm{~b} \\
(+59.57)^{*}\end{array}$ & $\begin{array}{c}0.18 \mathrm{a} \\
(+63.64)^{*}\end{array}$ & $\begin{array}{c}1.42 \mathrm{~b} \\
(+57.78)^{*}\end{array}$ \\
\hline Cow dung & $\begin{array}{c}6.17 b \\
(-4.78)^{*}\end{array}$ & $\begin{array}{l}0.014 \text { a } \\
(+180)^{*}\end{array}$ & $\begin{array}{c}24.82 \mathrm{a} \\
(+87.89)^{*}\end{array}$ & $\begin{array}{c}0.17 \mathrm{a} \\
(+54.55)^{*}\end{array}$ & $\begin{array}{c}1.68 \mathrm{a} \\
(+86.67)^{*} \\
\end{array}$ \\
\hline
\end{tabular}

$* \%$ increase or decrease relative to initial nutrient status of soil 
Cow dung management increased total-N, available-P and organic-C (\%) most from the initial level compared to control and crop residue management (Table 3). Exchangeable-K was statistically similar in crop residue and cow dung managements, and it was recorded minimum in control management. Several studies indicated that incorporation of organic amendments improve the soil health, increase the soil organic matter content, cation exchange capacity, water holding capacity, and soil nutrient status (macro and micro-nutrients) (Zhou et al. 2014; Salahin et al., 2017).

\section{Leaf area}

Leaf area of mungbean was influenced much by soil puddling and management practices are showed in Table 4. At $30 \mathrm{DAE}$, no puddling gave the highest leaf area which was significantly decreased with the increase of puddling intensity. At early stage no significant difference was observed for leaf area production in puddling by 4 and 8 passes situations. With age of the plant, leaf area production for no puddling and puddling by 4 passes had no significant differences. In contrast, puddling by 8 passes reduced leaf area significantly showing $19.44 \%$ less production in leaf area compared to no puddling and $10.29 \%$ less compared to puddling by 4 passes at 60 DAE. Leaf area production was always poor in case of puddling by 8 passes situation. Poor crop establishment and lower availability of nutrients under puddling situation followed by drying, resulting in a leaf area declination of mungbean (Zhou et al, 2014).

Table-4. Leaf area of mungbean as affected by puddling intensity and different management practices

\begin{tabular}{|l|c|c|c|c|c|}
\hline \multirow{2}{*}{\multicolumn{1}{|c}{ Treatments }} & \multicolumn{5}{c|}{ Leaf Area $\left(\mathbf{c m}^{2}\right)$} \\
\cline { 2 - 6 } & $\begin{array}{c}\mathbf{2 0} \\
\text { DAE }\end{array}$ & $\begin{array}{c}\mathbf{3 0} \\
\text { DAE }\end{array}$ & $\begin{array}{c}\mathbf{4 0} \\
\text { DAE }\end{array}$ & $\begin{array}{c}\mathbf{5 0} \\
\text { DAE }\end{array}$ & $\begin{array}{c}\mathbf{6 0} \\
\text { DAE }\end{array}$ \\
\hline Puddling intensity & & & & & \\
\hline No puddling & $32.8 \mathrm{a}$ & $149.4 \mathrm{a}$ & $271.3 \mathrm{a}$ & $382.7 \mathrm{a}$ & $314.8 \mathrm{a}$ \\
\hline Puddling by 4 passes & $30.0 \mathrm{~b}$ & $145.4 \mathrm{ab}$ & $261.0 \mathrm{a}$ & $372.4 \mathrm{a}$ & $282.7 \mathrm{~b}$ \\
\hline Puddling by 8 passes & $29.1 \mathrm{~b}$ & $141.2 \mathrm{~b}$ & $208.9 \mathrm{~b}$ & $310.4 \mathrm{~b}$ & $253.6 \mathrm{c}$ \\
\hline \multicolumn{7}{|c|}{ Management practices } \\
\hline Control & $29.4 \mathrm{~b}$ & $140.1 \mathrm{~b}$ & $235.9 \mathrm{~b}$ & $344.1 \mathrm{~b}$ & $268.1 \mathrm{~b}$ \\
\hline Crop residue & $29.1 \mathrm{~b}$ & $140.6 \mathrm{~b}$ & $241.1 \mathrm{~b}$ & $344.2 \mathrm{~b}$ & $274.0 \mathrm{~b}$ \\
\hline Cowdung & $33.4 \mathrm{a}$ & $155.3 \mathrm{a}$ & $264.2 \mathrm{a}$ & $377.2 \mathrm{a}$ & $309.0 \mathrm{a}$ \\
\hline LSD 0.05 & 2.70 & 6.09 & 11.82 & 18.12 & 25.29 \\
\hline
\end{tabular}

Different letters in the same column indicate significant difference (Duncan's test, $P<0.05$ ).

Cow dung management always showed better performance compared to other management practices in case of leaf area production. But no significant difference had been found for crop residue and control management. It can be explained that incorporation of cow dung adds some nitrogen to soil which helps in better leaf area production. There are evidences that increasing $\mathrm{N}$ level gave higher leaf area in legumes (Hossain, 1999, Wang et al., 2018).

\section{Root dry matter}

Main effects of soil puddling intensity and organic amendments on root dry matter of mungbean have been presented in Table 5. Puddling impaired root growth resulting reduced dry matter production and reduction in root dry matter increased as the intensity of puddling increased. Vepraskas (1988) reported that the root growth and development highly hampered in the drying puddled soil due to mechanical impedance. In this study, a significant reduction of root dry weight was found at $50 \mathrm{DAE}$, although puddling by 4 passes showed moderate root dry matter production at 40, 50 and $60 \mathrm{DAE}$ which is lower than no puddling but higher than puddling by 8 passes situation. This indicates that high puddling was having more deleterious effects for root development in mungbean plants. Several studies also revealed that root growth rates have been restricted for high mechanical impedance due to puddling and subsequent rapid soil drying processes (Fang et al. 2018).

Table-5. Root dry matter production of mungbean as affected by the puddling intensity and different management

\begin{tabular}{|l|c|c|c|c|c|}
\hline \multicolumn{1}{|c|}{ Treatments } & \multicolumn{5}{c|}{ Root dry matter (g/plant) } \\
\hline Puddling intensity & $\begin{array}{c}20 \\
\text { DAE }\end{array}$ & $\begin{array}{c}\text { DAE } \\
\text { DAE }\end{array}$ & $\begin{array}{c}50 \\
\text { DAE }\end{array}$ & $\begin{array}{c}60 \\
\text { DAE }\end{array}$ \\
\hline No puddling & 0.02 & 0.13 & $0.40 \mathrm{a}$ & $0.63 \mathrm{a}$ & $1.23 \mathrm{a}$ \\
\hline Puddling by 4 passes & 0.02 & 0.12 & $0.38 \mathrm{ab}$ & $0.59 \mathrm{ab}$ & $1.08 \mathrm{~b}$ \\
\hline Puddling by 8 passes & 0.02 & 0.12 & $0.34 \mathrm{~b}$ & $0.55 \mathrm{~b}$ & $1.03 \mathrm{~b}$ \\
\hline \multicolumn{6}{|c|}{ Management practices } \\
\hline Control & 0.02 & 0.13 & 0.36 & 0.58 & $1.01 \mathrm{~b}$ \\
\hline Crop residue & 0.02 & 0.13 & 0.37 & 0.59 & $1.09 \mathrm{ab}$ \\
\hline Cow dung & 0.02 & 0.13 & 0.38 & 0.59 & $1.14 \mathrm{a}$ \\
\hline LSD 0.05 & NS & NS & 0.04 & 0.05 & 0.07 \\
\hline
\end{tabular}

Different letters in the same column indicate significant difference (Duncan's test, $P<0.05$ ).

Management practices did not influence much on root dry matter production. At early stages no significant difference was found for different management practices for root dry matter production. But 


\section{Md Arafat Hossain et al.}

application of cow dung slightly improved root growth showing higher amount of root dry matter production compared to crop residue and control management at 60 DAE. This research finding agreed with those reported by Zhou et al. (2014) and Salahin et al. (2019). The higher soil porosity and enhanced nutrient uptake might have facilitated better growth and development of root under cow dung treatment.

\section{Total dry matter production}

The total dry matter (TDM) is the product of crop growth rate and growth duration (Khan et al., 2015) and it indicates the production ability of a crop. Main effects of puddling intensity and management practices on dry matter accumulation are given in Table 6. Irrespective of different management practices, TDM accumulations were significantly affected by puddling intensity. The highest TDM was recorded for no puddling situation and TDM decreased with the increase in puddling intensity. The most reduction in TDM (13.5\%) was observed for puddling by 8 passes at 60 DAE. Puddling by 4 passes also reduced TDM accumulation, but lesser extent compared to 8 passes. An increase in bulk density and mechanical impedance of puddled soil have been reported to well correlate with decrease growth of upland crops (Kirchhof et al., 2000). Several studies obtained destructive effects of puddling on soil physical properties for the morphological and physiological performance of subsequent non-rice crop (Singh et al., 2020).

Different management practices showed significant influence on the TDM accumulation. At 20 DAE crop residue and cow dung management showed similar result which was higher than control management. At 40 DAE cow dung management gave the maximum value, crop residue management showed moderate value and control management showed the minimum value. In case of 30, 50 and $60 \mathrm{DAE}$, cow dung management showed better performance compared to other management practices. The better crop performance under cow dung management might be attributed to inclusion of huge amount of N, P, and K into the soil (Salahin et al., 2019). But TDM production for crop residue and control management was statistically similar during this period.

Table-6. Total dry matter production of mungbean as affected by puddling intensity and different management practices

\begin{tabular}{|l|c|c|c|c|c|}
\hline \multirow{3}{*}{ Treatments } & \multicolumn{5}{|c|}{ Total dry matter $\left(\right.$ g plant $\left.^{-1}\right)$} \\
\cline { 2 - 6 } & $\begin{array}{c}20 \\
\text { DAE }\end{array}$ & 30 DAE & $\begin{array}{c}40 \\
\text { DAE }\end{array}$ & $\begin{array}{c}50 \\
\text { DAE }\end{array}$ & $\begin{array}{c}60 \\
\text { DAE }\end{array}$ \\
\hline \multicolumn{5}{|c|}{ Puddling intensity } \\
\hline No puddling & 0.28 & $1.32 \mathrm{a}$ & $3.15 \mathrm{a}$ & $5.41 \mathrm{a}$ & $9.49 \mathrm{a}$ \\
\hline Puddling by 4 passes & 0.26 & $1.26 \mathrm{ab}$ & $3.07 \mathrm{a}$ & $5.01 \mathrm{~b}$ & $8.66 \mathrm{~b}$ \\
\hline Puddling by 8 passes & 0.25 & $1.23 \mathrm{~b}$ & $2.74 \mathrm{~b}$ & $4.77 \mathrm{~b}$ & $8.21 \mathrm{~b}$ \\
\hline \multicolumn{5}{|c|}{ Management practices } \\
\hline Control & $0.23 \mathrm{~b}$ & $1.25 \mathrm{~b}$ & $2.83 \mathrm{~b}$ & $4.78 \mathrm{~b}$ & $8.25 \mathrm{~b}$ \\
\hline Crop residue & $0.27 \mathrm{a}$ & $1.20 \mathrm{~b}$ & $2.95 \mathrm{ab}$ & $4.97 \mathrm{~b}$ & $8.73 \mathrm{~b}$ \\
\hline Cow dung & $0.28 \mathrm{a}$ & $1.36 \mathrm{a}$ & $3.18 \mathrm{a}$ & $5.43 \mathrm{a}$ & $9.41 \mathrm{a}$ \\
\hline LSD $_{0.05}$ & 0.03 & 0.08 & 0.24 & 0.29 & 0.26 \\
\hline
\end{tabular}

Different letters in the same column indicate significant difference (Duncan's test, $P<0.05$ ).

Table-7. Mungbean seed yield and yield characters as influenced by soil puddling and different management practices

\begin{tabular}{|l|c|c|c|c|c|c|c|}
\hline \multicolumn{1}{|c|}{ Treatments } & $\begin{array}{c}\text { No. of pods per } \\
\text { plant }\end{array}$ & $\begin{array}{c}\text { No. of seeds } \\
\text { per pod }\end{array}$ & $\begin{array}{c}\text { No of seed } \\
\text { per plant }\end{array}$ & $\begin{array}{c}\text { Pod length } \\
\text { (cm) }\end{array}$ & $\begin{array}{c}\text { 1000-seed } \\
\text { weight }(\mathbf{g})\end{array}$ & $\begin{array}{c}\text { Seed yield } \\
\text { (g/plant) }\end{array}$ & $\begin{array}{c}\text { Harvest } \\
\text { index }\end{array}$ \\
\hline \multicolumn{8}{|c|}{ Puddling intensity } \\
\hline No puddling & $16.77 \mathrm{a}$ & 10.62 & $172.62 \mathrm{a}$ & 7.75 & $48.42 \mathrm{a}$ & $8.36 \mathrm{a}$ & 59.33 \\
Puddling by 4 passes & $15.85 \mathrm{~b}$ & 10.23 & $162.34 \mathrm{~b}$ & 7.48 & $46.74 \mathrm{~b}$ & $7.59 \mathrm{~b}$ & 58.75 \\
Puddling by 8 passes & $15.39 \mathrm{~b}$ & 10.28 & $163.45 \mathrm{~b}$ & 7.47 & $45.94 \mathrm{c}$ & $7.51 \mathrm{~b}$ & 57.75 \\
\hline \multicolumn{8}{|c|}{ Management practices } \\
\hline Control & $15.07 \mathrm{~b}$ & $10.46 \mathrm{ab}$ & $157.31 \mathrm{~b}$ & 7.58 & $46.64 \mathrm{~b}$ & $7.34 \mathrm{~b}$ & $57.42 \mathrm{~b}$ \\
Crop residue & $15.72 \mathrm{~b}$ & $9.98 \mathrm{~b}$ & $156.82 \mathrm{~b}$ & 7.62 & $47.07 \mathrm{ab}$ & $7.38 \mathrm{~b}$ & $57.83 \mathrm{~b}$ \\
Cow dung & $17.23 \mathrm{a}$ & $10.69 \mathrm{a}$ & $184.26 \mathrm{a}$ & 7.7 & $47.40 \mathrm{a}$ & $8.74 \mathrm{a}$ & $60.58 \mathrm{a}$ \\
\hline LSD 0.05 & 0.66 & 0.52 & 8.78 & NS & 0.59 & 0.43 & 1.25 \\
\hline
\end{tabular}

Different letters in the same column indicate significant difference (Duncan's test, $P<0.05$ ). 


\section{Yield and yield contributing characters}

Main effects of soil puddling and different management practices on yield contributing characters and seed yield of mungbean have been illustrated in Table 7. Puddling intensity had enormous influence in producing pods plant $^{-1}$. No puddling situation produced the highest number of pods (16.77 plant $\left.^{-1}\right)$. Number of pods decreased significantly with the increase of puddling intensity. However, number of seed pods ${ }^{-1}$ and pod length were not significantly influenced by puddling intensity. Seed yield differed greatly under various puddling intensity. The highest yield was recorded $8.36 \mathrm{~g}$ plant $^{-}$ ${ }^{1}$ in no puddling situation. The lowest was recorded $7.51 \mathrm{~g} \mathrm{plant}^{-1}$ in puddling by 8 passes which was $10.17 \%$ less compared to no puddling condition. Puddling by 4 passes also reduced seed yield by $9.21 \%$ in the study. On the contrary, Prastowo et al. (2007) and Kirchhof et al. (2000) reported that soil puddling imposed to rice had no significant effect on root length and yield of succeeding mungbean. Studies have revealed that poor upland crop performance in post-paddy soils associated with poor root growth and plant nutrient unavailability (Zhou et al. 2014).

In this study, the trend of reduction in seed yield and number of pods indicates that puddling intensity affected mostly the pod bearing capacity of plants. Harvest index showed almost similar trend as that of seed yield and number of pods.

Organic amendments significantly influenced the yield and yield contributing characters of plant (Table 7). Different management practices had significant effect in producing pods plant ${ }^{-1}$. Cow dung produced the maximum number of pods (17.23 plant $^{-1}$ ) compared to other management practices. For crop residue and control management, difference in number of pod was not significant. Number of seeds pod $^{-1}$ and thousand-seed weight were maximum at cow dung management which is followed by crop residue management and control management. However, pod length was not significantly influenced by management practices. Seed yield differed for various management practices. The highest yield was recorded $8.74 \mathrm{~g} \mathrm{plant}^{-1}$ in cow dung management. The lowest was recorded $7.34 \mathrm{~g} /$ plant in control management which is $16 \%$ less compared to cow dung management. Seed yield reduction trend and number of pods indicate that cow dung management affected mostly the pod bearing capacity of plants. Harvest index showed almost similar trend as that of seed yield and number of pods for all management practices. It can be explained that incorporation of organic amendments reduced the $\mathrm{N}$ requirement and improving the soil sub-surface mechanical impedance, resulting in better root growth, leaf area production, carbon assimilation, and seed yield (Memon et al., 2018).

Table-8. Interaction effects of soil puddling and different management practices on yield and yield attributing characters of mungbean

\begin{tabular}{|c|c|c|c|c|c|c|c|c|c|}
\hline \multirow{2}{*}{$\begin{array}{l}\text { Puddling } \\
\text { intensity }\end{array}$} & \multirow{2}{*}{$\begin{array}{c}\text { Management } \\
\text { practice }\end{array}$} & \multicolumn{8}{|c|}{ Yield characters } \\
\hline & & $\begin{array}{l}\text { Pod length } \\
\text { (cm) }\end{array}$ & $\begin{array}{c}\text { No. of pod/ } \\
\text { plant }\end{array}$ & $\begin{array}{c}\text { No. of } \\
\text { seed/Pod }\end{array}$ & $\begin{array}{c}1000 \text { seed } \\
\text { wt. }(\mathrm{gm})\end{array}$ & $\begin{array}{c}\text { Seed yield } \\
\text { (g/plant) }\end{array}$ & \begin{tabular}{|c|}
$\begin{array}{c}\text { Seed yield } \\
\text { ton/ha) }\end{array}$ \\
\end{tabular} & $\begin{array}{c}\text { Straw yield } \\
\text { (g/plant) }\end{array}$ & HI \\
\hline \multirow{3}{*}{$\begin{array}{l}\text { No } \\
\text { puddling }\end{array}$} & Control & 7.94 & $15.73 \mathrm{c}$ & $10.00 \mathrm{bc}$ & $47.93 \mathrm{ab}$ & $7.51 \mathrm{~cd}$ & $1.69 \mathrm{bc}$ & 5.51 & $57.14 \mathrm{ab}$ \\
\hline & Crop residue & 7.93 & $16.08 \mathrm{bc}$ & $10.23 \mathrm{a}-\mathrm{c}$ & $48.65 \mathrm{a}$ & $7.97 \mathrm{bc}$ & $1.70 \mathrm{~b}$ & 5.59 & $57.51 \mathrm{ab}$ \\
\hline & Cow dung & 7.95 & $18.52 \mathrm{a}$ & $10.98 \mathrm{a}$ & $48.7 \mathrm{a}$ & $9.59 \mathrm{a}$ & $1.76 \mathrm{a}$ & 5.91 & $62.01 \mathrm{a}$ \\
\hline \multirow{3}{*}{$\begin{array}{l}\text { Puddling } \\
\text { by } 4 \text { passes }\end{array}$} & Control & 7.43 & $15.15 \mathrm{~cd}$ & $10.80 \mathrm{ab}$ & $46.40 \mathrm{~cd}$ & $7.59 \mathrm{~cd}$ & $1.65 \mathrm{cde}$ & 5.59 & $58.03 \mathrm{ab}$ \\
\hline & Crop residue & 7.46 & $15.32 \mathrm{~cd}$ & $9.425 \mathrm{c}$ & $46.50 \mathrm{~cd}$ & $6.72 \mathrm{e}$ & $1.67 \mathrm{bcd}$ & 4.91 & $57.71 \mathrm{ab}$ \\
\hline & Cow dung & 7.53 & $17.08 \mathrm{~b}$ & $10.48 \mathrm{ab}$ & $47.33 b c$ & $8.46 \mathrm{~b}$ & $1.70 \mathrm{~b}$ & 5.57 & $60.51 \mathrm{ab}$ \\
\hline \multirow{3}{*}{$\begin{array}{l}\text { Puddling } \\
\text { by } 8 \text { passes }\end{array}$} & Control & 7.39 & $14.32 \mathrm{~d}$ & $10.57 \mathrm{ab}$ & $45.60 \mathrm{~d}$ & $6.91 \mathrm{de}$ & $1.61 \mathrm{e}$ & 5.24 & $56.70 \mathrm{~b}$ \\
\hline & Crop residue & 7.47 & $15.75 \mathrm{c}$ & $10.30 \mathrm{a}-\mathrm{c}$ & $46.05 \mathrm{~d}$ & $7.46 \mathrm{cde}$ & $1.61 \mathrm{e}$ & 5.55 & $57.25 \mathrm{~b}$ \\
\hline & Cow dung & 7.61 & $16.10 \mathrm{bc}$ & $10.63 \mathrm{ab}$ & $46.17 \mathrm{~d}$ & $8.17 \mathrm{bc}$ & $1.63 \mathrm{de}$ & 5.55 & $59.29 \mathrm{ab}$ \\
\hline \multicolumn{2}{|c|}{$\operatorname{LSD}_{0.05}$} & NS & 1.15 & 0.91 & 1.02 & 0.74 & 0.05 & 0.55 & 4.61 \\
\hline
\end{tabular}

Different letters in the same column indicate significant difference (Duncan's test, $P<0.05$ ). 
Interaction effects of soil puddling and management practices on yield attributes and seed yield of mungbean were significantly affected by the treatments (Table 8). The seed yield attributing parameters of mungbean decreased with the increase of puddling intensity for all management practices. However, the depressed plant characters and the seed yield varied greatly with the intensity of puddling and to some extent for different nitrogen levels. Puddling by 8 passes reduced the number of pods by $13-23 \%$ depending on management practices. Such reduction in pods ranged from 8-19\% for puddling by 4 passes. However, seed yield reduction for puddling by 8 passes was $0-11 \%$ and up to $9 \%$ by 4 passes. Application of cow dung increased seed yield to a great extent, perhaps mainly due to improving the depressed plant characters like pod length, seed weight and higher harvest index. Thus, application of cow dung is a possible option to mitigate the deleterious effects of puddling in post-rice mungbean production.

\section{Conclusion}

Puddling intensity adversely affected soil strength and bulk density. Application of cow dung increased total$\mathrm{N}$ (75.0\%), available-P (35.5\%), exchangeable-K (13.3\%) and organic-C content (38.8\%) of puddled soil compared to without amendment. Puddling (8 passes) impaired root growth resulting reduced dry matter production compared to control treatment by $15.6 \%$. Cow dung application at rates of $6.04 \mathrm{t} \mathrm{ha}^{-1}$ in puddled soil improved mungbean root growth and total plant dry matter attributing higher seed yield by $16 \%$ over control. Detailed study on soil puddling and associated plant characters like root nodules, root growth and application of other management practices i.e. application of other soil amendments like gypsum (SA), cultivation by zero tillage should be given emphasis to address the problem of puddled soil.

\section{Disclaimer: None.}

Conflict of Interest: None.

Source of Funding: None.

\section{References}

Adams JE, 1934. Determination of Total Carbon in Soils by the Wet Oxidation Method. Ind. Eng. Chem - Anal. Ed. 6: 277-279.

Bajpai RK and Tripathi RP, 2000. Evaluation of non- puddling under shallow water tables and alternative tillage methods on soil and crop parameters in a rice-wheat system in Uttar Pradesh. Soil Tillage Res. 55: 99-106.

BBS, 2019. Bangladesh Bureau of Statistics, Statistical Yearbook of Bangladesh, Statistics Division, Ministry of Planning, Dhaka, Bangladesh.

Becker M, Asch F, Chiem NH, Ni DV, Saleh E, Tanh KV and Tinh TK, 2008. Decomposition of Organic Substrates and their Effect on Mungbean Growth in Two Soils of the Mekong Delta Decomposition of Organic Substrates and their Effect on Mungbean Growth in Two Soils of the Mekong Delta. J. Agric. Rural Develop. Trop. Subtrop. 109: 95-108.

Bell RW, Haque ME, Jahiruddin M, Rahman MM, Begum M, Miah MAM, Islam MA, Hossen MA, Salahin N, Zahan T, Hossain MM, Alam MK and Mahmud MNH, 2019. Conservation agriculture for rice-based intensive cropping by smallholders in the eastern Gangetic plain. Agric. 9: 5.

Blake GR, 1965. 'Bulk Density', in C. A. Black (ed.), Methods of Soil Analysis, Part I. Agronomy. Am. Soc. Agron. Madison, Wisconsin, USA. pp. 374377.

Chu GX, Shen QR and Cao JL, 2004. Nitrogen fixation and $\mathrm{N}$ transfer from peanut to rice cultivated in aerobic soil in an intercropping system and its effect on soil $\mathrm{N}$ fertility. Plant Soil. 263: 17-27.

Fang H, Zhou H, Norton GJ, Price AH, Raffan AC, Mooney SJ, Peng X and Hallett PD, 2018. Interaction between contrasting rice genotypes and soil physical conditions induced by hydraulic stresses typical of alternate wetting and drying irrigation of soil. Plant Soil. 430: 233-243.

Gomez KA and Gomez AA, 1994. 'Statistical Procedure for Agricultural Research', 2nd Edition, International Rice Research Institute, John Wiley and Sons, New York. pp. 1-340.

Harris D, Joshi A, Khan PA, Gothkar P and Sodhi PS, 1999. On-farm seed priming in semi-arid agriculture: Development and evaluation in maize, rice and chickpea in India using participatory methods. Exper. Agric. 35: 15-29.

Hossain MA, 1999. Root growth, nutrient uptake and yield performance of groundnut genotypes as influenced by nitrogen and phosphorus fertilization. Ph.D. Thesis, Department of Agronomy, BSMRAU, Gazipur, Bangladesh. 
Hou D, Yousaf L, Xue Y, Hu J, Wu J, Hu X, Feng N and Shen Q, 2019. Mung bean (Vigna radiata L.): Bioactive polyphenols, polysaccharides, peptides, and health benefits. Nutrients. 11: 1-28.

Khan M, Karim M, Haque M, Karim A and Mian M, 2015. Growth and dry matter partitioning in selected soybean (Glycine max L.) genotypes. Bangladesh J. Agric. Res. 40: 333-345.

Kirby JM and Ringrose-Voase AJ, 2000. Drying of some Philippine and Indonesian puddled rice soils following surface drainage: Numerical analysis using a swelling soil flow model. Soil Tillage Res. 57: 13-30.

Kirchhof G, Priyono S, Utomo WH, Adisarwanto T, Dacanay EV and So HB, 2000. The effect of soil puddling on the soil physical properties and the growth of rice and post-rice crops. Soil Tillage Res. 56: 37-50.

Kramarenko VV, Nikitenkov AN, Matveenko IA, Molokov VY and Vasilenko YS, 2016. Determination of water content in clay and organic soil using microwave oven. IOP Conf. Ser. Earth Environ. Sci. 43: 012029.

Lim S, Yang HI, Park H, Park S, Seo B, Lee K, Lee S, Lee S, Kim H, Ryu J, Kwak J and Choi W, 2020. Land-use management for sustainable rice production and carbon sequestration in reclaimed coastal tideland soils of South Korea : a review. Soil Sci. Plant Nutr. 66: 60-75.

Memon MS, Guo J, Tagar AA, Perveen N, Ji C, Memon SA and Memon N, 2018. The Effects of Tillage and Straw Incorporation on Soil Organic Carbon Status, Rice Crop Productivity, and Sustainability in the Rice-Wheat Cropping System of Eastern China. Sustainability. 10: 961.

Murphy VA, 1987. Method for determination of sodium, potassium, calcium, magnesium, chloride, and phosphate in the rat choroid plexus by flame atomic absorption and visible spectroscopy. Anal. Biochem. 161: 144-151.

Musa AM, Harris D, Johansen C and Kumari J, 2001. Short duration chickpea to replace fallow after Aman rice: The role of on-farm seed priming in the high barind tract of Bangladesh. Exper. Agric. 37: 509-521

Obalum SE, Oppong J, Nwite JC, Watanabe Y, Buri MM, Igwe CA and Wakatsuki T, 2012. Longterm effects of lowland sawah system on soil physicochemical properties and rice yield in Ashanti Region of Ghana. Spanish J. Agric. Res. 10: 838-848.
Olsen SR, Cole CV, Watanabe FS and Dean LA, 1954. Estimation of Available Phosphorus in Soils by Extraction with Sodium Bicarbonate. U. S. Department of Agriculture Circular No. 939. Washington DC, USA.

Phogat VK and Dahiya SS, 2012. Alleviating Soil Physical Constraints for Sustainable Crop Production through Tillage, Soil Amendment and Crop Residue Management Alleviating Soil Physical Constraints for Sustainable Crop Production through Tillage, Soil Amendment and Crop Residue Mana. 12th ISCO Conf. Beijing 2002. 415-420.

Prastowo S, Hardjoamidjojo B and Murtilaksono K, 2007. Performance of shallow groundwater irrigation schemes in Nganjuk, East Java, Indonesia. CIGR J. IX: 11.

Rahmianna AA, Adisarwanto T, Kirchhof $\mathrm{G}$ and So $\mathrm{HB}, 2000$. Crop establishment of legumes in rainfed lowland rice-based cropping systems, Research Institute for Food Legumes and Tuber Crops, Kendalpayak, Malang 65101, Indonesia.

Rezaei M, Tabatabaekoloor R, Mousavi seyedi SR and Aghili Nategh N, 2012. Effects of puddling intensity on the in-situ engineering properties of paddy field soil. Aust. J. Agric. Eng. 3: 22-26.

Salahin N, Alam K, Mondol ATMAI, Islam MS, Rashid MH and Hoque MA, 2017. Effect of tillage and residue retention on soil properties and crop yields in Wheat-Mungbean-Rice Crop rotation under subtropical humid climate. Open J. Soil Sci. 7:1-17.

Salahin N, Alam MK, Shil NC, Mondol ATMAI and Alam MJ, 2019. Effects of tillage practices and nutrient management. Bangladesh J. Agric. Res. 44: 387-399.

Singh M, Kumar P, Virender K, Solanki IS, Mcdonald AJ, Kumar A, Poonia SP, Kumar V, Ajay A, Kumar A, Singh DK, Singh B, Singh S and Malik RK, 2020. Inter comparison of crop establishment methods for improving yield and profitability in the rice-wheat system of Eastern India. F. Crop. Res. 250: 107776.

Srinivasarao CH, Kundu S, Lakshmi CS, Rani YS, Nataraj KC, Gangaiah B, Laxmi MJ, Babu MVS, Rani U, Nagalakshmi S and Manasa R, 2019. Soil Health Issues for Sustainability of South Asian Agriculture. EC Agric. 44: 310-326.

Vepraskas MJ, 1988. Bulk density values diagnostic of restricted root growth in coarse textured soil. 
Md Arafat Hossain et al.

Soil Sci. Soc. Am. J. 52: 1117-1121.

Wang X, Guo X, Yu Y, Cui H, Wang R and Guo W, 2018. Increased nitrogen supply promoted the growth of non-N- fixing woody legume species but not the growth of N-fixing Robinia pseudoacacia. Sci. Rep. 8: 1-9.

Williams H, Colombi T, and Keller T, 2020. The influence of soil management on soil health: An on-farm study in southern Sweden. Geoderma. 360: 114010.

Yuvaraj M, 2020. Soil Physical Constraints and Management Technologies. Res. Today. 2: 85-86. Zhou W, Lv TF, Chen Y, Westby AP and Ren WJ,
2014. Soil Physicochemical and Biological Properties of Paddy-Upland Rotation: A Review. The Sci. World J. 2014:1-8.

\section{Contribution of Authors}

Hossain MA: Designed research methodology, performed experiment and approved the manuscript

Rana MD: Helped in data analysis and manuscript write up

Al Rabbi SMH: Provided experimental inputs and helped in manuscript write up

Mitsui T: Manuscript write up and approval 